Bull. Fac. Agric., Cairo Univ.,64: 348- 357 (2013).

\title{
COMBINING ABILITY ANALYSIS USING DOUBLE CROSS HYBRIDS IN MAIZE
}

(Received: 6.12.2013)

\author{
By \\ M. A. H. Al-Falahy \\ Faculty of Agriculture and Forestry, University of Duhok, Iraq
}

\begin{abstract}
The inbred lines of maize ZP-301, IK58, ZP707, OH40, DK17 and UN44052 and all double cross hybrids among them were used in this study. The seeds of genotypes (6 lines and 45 double cross hybrids) were planted at the field of the Faculty of the Agriculture and Forestry College, Duhok University, Iraq on 15 March 2012. The analysis of variance for the double cross hybrids revealed the presence of additive and non-additive effects. The non-additive genetic effects (dominance and epistasis) were more important in the inheritance of all the studied characters. Therefore, the appropriate breeding method that can be adopted to improve these characters is either the production of hybrid varieties or through recurrent selection for specific combining ability. The inbred line ZP707 exhibited desirable combining ability effects for all the studied characters except ear height, followed by inbred line IK58, which showed desirable general combining baility effects for the number of days to silking, plant height ear height, 300 grain weight and grain yield per plant. The double cross hybrids (ZP301xZP707) x (ZP301xOH40) and (ZP301xUN44052)x(OH40xDK17) performed well for all characters and could be used in future breeding programs.
\end{abstract}

Key words: Zea mays, double crosses, gen action, line interaction effects.

\section{INTRODUCTION}

Double-cross hybrids were considered the first commercial maize hybrid cultivar available to farmers. This fact was possible due to the work developed by Jones in the early part of the $20^{\text {th }}$ century (Troyer, 2009). In most countries, the current studies indicate that high percentage of the seed market involves double-cross hybrid cultivars (Cruz and Pereira Filho, 2008). Various seed companies maintain these cultivars in order to exploit the heterosis that exists among pairs of single-cross hybrids (Jenkins, 1934).

In most countries, local production of grain maize is encouraged to minimize the cost of constraints as a consequence of producing hybrid seed on the low vigor and yield parents. To overcome this, Jones $(1918,1922)$ suggested the use of double cross hybrids in maize. A double cross hybrid results from the cross between two single crosses that are themselves the result of crosses between two selected inbred lines (Hallauer and Miranda, 1982). For successful double cross hybrid development, heterotic effects have to be maximized, and the best results are expected when four unrelated or diverse inbred lines are used. Although double cross hybrids show slightly higher variation in plant and ear characters as compared to single crosses, which might affect the grain yield, the cost of seed production could be reduced because they are produced on single cross hybrids as parents, which produce more seeds compared to inbred parents, as in the case of single cross hybrids (Jugenheimer 1976 and Stoskopf et al., 1993).

Testing and selection of superior inbred lines for their combining ability for hybrid production demand a great amount of effort. When a high number of inbred lines are tested, the possible number of hybrid combinations to be evaluated is tremendously high. This poses a lot of practical difficulties in conducting extensive yield tests. Therefore, with the ability to accurately predict the performance of double cross hybrids from the performance of single crosses, only promising double crosses need to be developed and the yield performance confirmed in actual yield tests. This would effectively facilitate double cross hybrid development. Several methods of making predictions of performance of double cross hybrids based on performance of single crosses 
were proposed. However, the most accurate prediction was found to be the mean value of the four non-parental single crosses (Allard 1970). ElHashash (2013) reported that significant or highly significant differences in most studied traits appeared due to different genotypes (parents, single and double-cross hybrids). Mean performance of some single crosses was higher than the double-cross hybrids for most studied traits. The single-cross hybrid (Pima S6 $x$ Australian) and the double-cross hybrid (Pima S6 x Australian) x (Karashanky x Giza 88) were the best mean performances for most studied traits.

The main objectives of this study were to evaluate the performance of some double cross hybrids developed from previously selected single crosses, and to estimate the general combining ability effects of the parents and specific combining ability effects of the different kinds of different hybrid combination among parents.

\section{MATERIALS AND METHODS}

Six inbred lines of maize: (1) ZP-301, (2) IK58,3) ZP707, (4) OH40, (5) DK17 and (6) UN44052 were crossed in a diallel fashion according to Method 2 of Griffing (1956) during spring season of 2010 . The $21 \mathrm{~F}_{1}$ s were planted during spring season 2011 at the field of Faculty of Agriculture and Forestry, Duhok University, Iraq, and all possible double crosses among them were done according to the method outlined by Rawlings and Cockerham (1962) to obtain 45 double cross hybrids. The resulting 45 double cross hybrids along with their six parents were planted at the same field in 15 March 2012, using a randomized complete block design with three replications. Each plot consisted of one row of $5 \mathrm{~m}$ length. The spacing between rows was $0.75 \mathrm{~m}$ and plant to plant spacing was $0.20 \mathrm{~m}$. One plant per hill was maintained. Fertilizers were applied at the rate of $680 \mathrm{~kg}$ per hectare, one month of NPK (18:23:0) before planting, and $\mathrm{N}$ as urea at the rate of $200 \mathrm{~kg}$ per hectare, a month after planting.

Observations were recorded on ten randomly selected guarded plants from each plot for number of days to silking (NDS), plant height $(\mathrm{cm})(\mathrm{pH})$, ear height $(\mathrm{cm})(\mathrm{EH})$, ear height $(\mathrm{cm})(\mathrm{EH})$, number of rows per ear (NRE), number of grains per row (NGR), 300 grain weight $(\mathrm{g})(300 \mathrm{~g})$ and grain yield per plant (gm) (GYP).

Data of the parents, the hybrids (each alone) and all genotypes (parents and hybrids), for all studied traits, were subjected to analysis of variance according to the experimental design used, and comparisons between means were done according to Duncan's Multiple Range Test method (Gomez and Gomez, 1983). The data of the double cross hybrids were subjected to analysis of variance according to the method of Rawlings and Cockerham (1962) (Fixed Model), proportional contribution of each source of variation estimated as percentage of its sum square to total sum of square of hybrids). General combining ability (gca) effects of the parents was estimated. All kinds of specific combining ability (sca) effects were also estimated as follows: (1) The 2-line interaction effects of lines $\mathrm{i}$ and $\mathrm{j}$ appearing together irrespective of arrangement, (2) The 3line interaction effect of lines $\mathrm{i}, \mathrm{j}$ and $\mathrm{k}$ appearing together irrespective of arrangement, (3) The 4line interaction effects of lines $\mathrm{i}, \mathrm{j}, \mathrm{k}$ and 1 appearing together irrespective of arrangement, (4) The 2-line interaction effect of lines $i$ and $j$ due to a particular arrangement (ij)(--), (5) The 2-line interaction effect of lines $i$ and $j$ due to a particular arrangement (i-)(j-), (6) The 3-line interaction effect of lines $i, j$ and $k$ due to a particular arrangement (ij)(k-), (7) The 4-line interaction effect of lines $\mathrm{i}, \mathrm{j}, \mathrm{k}$ and $\mathrm{l}$ due to a particular arrangement (ij)(kl), using the methods explained by Singh and Chaudhary (2007). All statistical and genetical analysis were performed by using SAS (Statistical Analysis System V. 9) and Microsoft Office Excel 2003.

\section{RESULTS AND DISCUSSION}

Analysis of variance of all genotype data (parents and all possible double cross hybrids), parents and hybrids (each alone) for the studied characters is presented in Table (1). It is shown that the mean square of the genotypes, parents, hybrids and parents vs hybrids were highly significant for all characters. The highly significant mean of squares due to the genotypes indicate genetic differences among them, and this requires partitioning of hybrid means of squares to its components according to the method of Rawlings and Cockerham (1962), to identify the nature of gene action that controls the genetic inheritance of the characters under study. The results of this partitioning are illustrated in Table (2) indicated that the mean of squares for all sources of variations (1-Line general, 2-line specific, 2-line arrangement, 3-line arrangement and 4-line arrangement) was highly significant for all characters. Singh and Chaudhary (2007) noted that the 1-line average effect accounts for the total additive effects except for a small portion contained in the error. Obviously, if the gene action is primarily of the additive type, the 


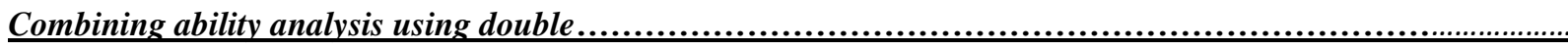

Table (1): ANOVA of genotypes data for grain yield and some studied traits.

\begin{tabular}{|c|c|c|c|c|c|c|c|c|}
\hline \multirow{2}{*}{ Source } & \multirow{2}{*}{ df } & \multicolumn{7}{|c|}{ MS } \\
\hline & & NDS & PH & EH & NRE & NGR & $300 \mathrm{~g}$ & GYP \\
\hline Reps. & 2 & 0.674 & 79.489 & 72.385 & 0.141 & 37.489 & 20.42 & 143.052 \\
\hline Genotypes & 50 & $22.22 * *$ & $1429.9 * *$ & $720.8 * *$ & $7.80 * *$ & 59.86** & $128.27 * *$ & 2757.9** \\
\hline Parents (P) & 5 & $16.633 * *$ & 383.73** & $690.86 * *$ & $3.60 * *$ & 49.07** & $66.53 * *$ & 479.85** \\
\hline Hybrids (H) & 44 & $22.61 * *$ & $1131.8 * *$ & 671.0** & $8.220 * *$ & $56.93 * *$ & $107.07 * *$ & $2266.1 * *$ \\
\hline P vs H & (1) & 33.31** & $19778.4^{* *}$ & $3062.1 * *$ & $10.4 * *$ & $242.95 * *$ & $1369.9 * *$ & $35787.5 * *$ \\
\hline Error & 100 & 0.377 & 8.849 & 8.035 & 0.207 & 2.086 & 1.612 & 4.128 \\
\hline
\end{tabular}

$(* *)$ significant at $1 \%$ level of probability.

Table (2): ANOVA of double crosses data for grain yield and some studied traits.

\begin{tabular}{|c|c|c|c|c|c|c|c|c|}
\hline \multirow{2}{*}{ Source } & \multirow{2}{*}{ df } & \multicolumn{7}{|c|}{ MS } \\
\hline & & NDS & PH & EH & NRE & NGR & $300 \mathrm{~g}$ & GYP \\
\hline Hybrids (H) & 44 & $22.61 * *$ & $1131.8 * *$ & 671.0** & $8.220 * *$ & $56.93 * *$ & $107.07 * *$ & $2266.1 * *$ \\
\hline 1-line general & 5 & $26.09 * *$ & $298.83 * *$ & $237.2 * *$ & $7.852 * *$ & $34.22 * *$ & 70.15** & $1124.8 * *$ \\
\hline 2-line specific & 9 & $16.88 * *$ & $1898.3 * *$ & $1009.3 * *$ & $9.057 * *$ & 67.88** & $64.83 * *$ & $3058.3 * *$ \\
\hline 3-line specific* & & -- & -- & -- & -- & -- & -- & -- \\
\hline 4-line specific* & & -- & -- & -- & -- & -- & -- & -- \\
\hline 2-line arrang. & 9 & $23.48 * *$ & 1511.7** & $1335.5 * *$ & $5.225 * *$ & $57.17 * *$ & $165.69 * *$ & $2763.9 * *$ \\
\hline 3-line arrang. & 16 & $19.53 * *$ & $704.92 * *$ & $332.6 * *$ & $7.385 * *$ & $65.56 * *$ & $116.86 * *$ & $2189.0 * *$ \\
\hline 4-line arrang. & 5 & $37.67 * *$ & $1266.8 * *$ & 382.7** & $15.14 * *$ & 31.88** & $83.15 * *$ & $1332.3 * *$ \\
\hline Error & 88 & 0.394 & 6.966 & 7.522 & 0.141 & 1.829 & 1.717 & 3.844 \\
\hline \multicolumn{9}{|c|}{ Proportional contribution of the following sources to total variance of hybrids (\%) } \\
\hline \multicolumn{2}{|c|}{ 1- line general } & 13.118 & 3.001 & 4.017 & 10.855 & 6.831 & 7.446 & 5.641 \\
\hline \multicolumn{2}{|c|}{ 2- line specific } & 15.275 & 34.309 & 30.767 & 22.538 & 24.389 & 12.385 & 27.605 \\
\hline \multicolumn{2}{|c|}{ 2- line arrang. } & 21.247 & 27.322 & 40.711 & 13.002 & 20.542 & 31.655 & 24.947 \\
\hline \multicolumn{2}{|c|}{ 3- line arrang. } & 31.420 & 22.649 & 18.024 & 32.672 & 41.875 & 39.689 & 35.126 \\
\hline \multicolumn{2}{|c|}{ 4- line arrang. } & 18.939 & 12.719 & 6.481 & 20.932 & 6.363 & 8.825 & 6.681 \\
\hline
\end{tabular}

Table ( 3): Range and means of parents and double cross hybrids for grain yield and studied traits.

\begin{tabular}{|c|c|c|c|c|c|c|c|}
\hline \multirow{2}{*}{ Traits } & \multicolumn{2}{|c|}{ Range of parents } & \multirow{2}{*}{$\begin{array}{l}\text { Parents } \\
\text { mean }\end{array}$} & \multicolumn{2}{|c|}{ Range of hybrids } & \multirow{2}{*}{$\begin{array}{c}\text { Hybrids } \\
\text { mean }\end{array}$} & \multirow{2}{*}{$\begin{array}{c}\text { General } \\
\text { mean }\end{array}$} \\
\hline & Lower & Higher & & Lower & Higher & & \\
\hline NDS & $\begin{array}{c}72.667 \text { c } \\
(\mathbf{U N 4 4 0 5 2 )}\end{array}$ & $\begin{array}{l}77.667 \text { a } \\
(\text { ZP707) }\end{array}$ & 74.500 & $\begin{array}{c}68.333 \mathrm{n} \\
(12) \times(35) \\
\end{array}$ & $\begin{array}{c}79.000 \text { a } \\
(14) \times(23)\end{array}$ & $75.948 * *$ & 75.778 \\
\hline $\begin{array}{c}\mathbf{P H} \\
(\mathrm{cm})\end{array}$ & $\begin{array}{l}127.667 \text { c } \\
(\text { ZP707) }\end{array}$ & $\begin{array}{c}154.667 \text { a } \\
\text { (IK58) }\end{array}$ & 142.333 & $\begin{array}{c}141.67 \mathrm{u} \\
(15) \times(36)\end{array}$ & $\begin{array}{c}227.333 a \\
(14) \times(56)\end{array}$ & $177.622 * *$ & 173.471 \\
\hline $\begin{array}{c}\mathbf{E H} \\
(\mathbf{c m})\end{array}$ & $\begin{array}{c}54.667 \text { d } \\
(\mathrm{UN44052})\end{array}$ & $\begin{array}{c}97.333 \text { a } \\
\text { (DK17) }\end{array}$ & 70.389 & $\begin{array}{c}60.000 s \\
(16) \times(35)\end{array}$ & $\begin{array}{l}131.667 a \\
(14) \times(56)\end{array}$ & $84.274 * *$ & 82.641 \\
\hline NRE & $\begin{array}{l}12.667 \text { c } \\
\text { (ZP707) }\end{array}$ & $\begin{array}{c}16.000 \text { a } \\
\text { (IK58) }\end{array}$ & 14.333 & $\begin{array}{c}12.000 \mathrm{f} \\
(12) \times(34)\end{array}$ & $\begin{array}{l}18.667 \text { a } \\
(13) \times(56)\end{array}$ & $15.141 * *$ & 15.046 \\
\hline NGR & $\begin{array}{l}21.000 \text { e } \\
(Z P 707)\end{array}$ & $\begin{array}{c}31.667 \text { a } \\
(\text { IK58) }\end{array}$ & 26.000 & $\begin{array}{c}22.333 \mathrm{r} \\
(34) \times(56)\end{array}$ & $\begin{array}{l}40.667 \text { a } \\
(16) \times(34)\end{array}$ & 29.911** & 29.451 \\
\hline $300 \mathrm{~g}$ & $\begin{array}{l}\text { 34.580 d } \\
\text { (ZP301) }\end{array}$ & $\begin{array}{c}48.367 \text { a } \\
\text { (UN44052) }\end{array}$ & 42.503 & $\begin{array}{l}36.723 q \\
(13) \times(46)\end{array}$ & $\begin{array}{c}67.193 \mathrm{a} \\
(16) \times(34)\end{array}$ & $51.790 * *$ & 50.698 \\
\hline $\begin{array}{c}\text { GYP } \\
(\mathbf{g})\end{array}$ & $\begin{array}{l}33.063 \mathrm{~d} \\
\text { (ZP301) }\end{array}$ & $\begin{array}{c}\text { 67.777 a } \\
\text { (IK58) }\end{array}$ & 43.164 & $\begin{array}{l}47.593 \mathrm{u} \\
(15) \times(26)\end{array}$ & $\begin{array}{l}160.547 \mathrm{a} \\
(13) \times(56)\end{array}$ & $90.633 * *$ & 85.048 \\
\hline
\end{tabular}


estimates of 1-line effects are sufficient to predict the hybrid performance.

The average 2-line effects represent non-additive type of gene action. Similarly, the average 3-line effects are the function of additive $\mathrm{x}$ dominance interaction including all 3-factors or higher order interactions except for the all-dominance types. The average 4-line effects represent dominance $\mathrm{x}$ dominance interactions and all 3-factors interactions, except all-additive types. The effects arising due to the arrangement of lines are exclusively the results of dominance effects or interactions involving dominance components. Another most important aspect of double-cross hybrids is the relative importance of arrangement of parents, the order effect, in these hybrids. A critical analysis of the combining ability effects of higher order provides evidence for the relative significance of order in which the parents have been involved in a double-cross hybrid. It is shown from Table (2) that the proportional contribution of 1- line general to total variance of hybrids was less than that other sources of variation. This shows that non-additive genetic effects (dominance and epistasis of this type) was more important in the inheritance of all studied characters. Table (3) illustrates the range and means of parents and double cross hybrids for grain yield and some of studied traits in maize. It is clear that there were significant differences among parents and double cross hybrids for all characters. It seems that the highest values in the double cross hybrids was more than their counterparts in parents with high percentage for all characters, and that the general mean of double cross hybrids was higher than that in the parents and the general mean of genotypes. This indicates that there are indicators for significant desirable heterosis in many double cross hybrids, which in turn is an indication of the importance of dominance gene action and epistasis of dominant type in the inheritance of all these characters. Table (4) shows that the inbred line IK58 surpassed other lines by giving higher values for characters $\mathrm{PH}, \mathrm{NRE}$, NGR and GYP, and the double cross hybrids (14) $\mathrm{x}(56)$ (i), (14) $\mathrm{x}(56)$, (13) $\mathrm{x}(56)$ (i), (16) $\mathrm{x}(34)$ (i), (16) $\mathrm{x}(34)$ (ii) and (13) $\mathrm{x}(56)$ (ii) were characterized by higher mean values for PH, EH, NRE, NGR, 300 gw and GYP, respectively. While the line UN44052 and hybrid (12) $\mathrm{x}(35)$ appeared to be the earliest maturating, as they gave the lowest number of days to silking. Estimate of general combining ability effects of pure lines of maize for different characters are presented in characters, except for $\mathrm{EH}$, followed by pure line IK58, which showed desirable general combining effects for NDS, $\mathrm{PH}, \mathrm{EH}, 300$ $\mathrm{g}$ and GYP, while inbred lines ZP301, OH40, DK17 and UN44052 showed desirable general combining effects for $3,1,2$ and 2 characters, respectively. These results indicate the possibility of adopting discriminating parents in their general combining ability effects for more number of characters in future breeding programs to improve crop characters. The 2-line interaction effects of lines $i$ and $j$ appearing together irrespective of the arrangement are presented in Table (5). It was shown that 7,8,9 and $10 \mathrm{~S}_{2 \mathrm{ij}}$ interactions gave desirable effects for NDS, PH, EH and NRE, respectively, while desirable effects appeared in six interactions for each of the characters NGR, $300 \mathrm{~g}$ and GYP. The interaction $\mathrm{S}_{25}$ showed specific effects in the desired direction for all characters, except $300 \mathrm{~g}$, followed by the interactions $S_{23}, S_{35}$ and $S_{36} S_{36}$, each of which gave desirable effects for five characters only. Data comparing the behavior of bilateral interaction of lines, irrespective of the arrangement, towards different characters with the results of bilateral interactions according to the arrangements $S_{(\mathrm{ij})(.)}$ and $\mathrm{S}_{(\mathrm{i})(\mathrm{j}-)}$ are given in Tables (6 and 7). There are clear differences in the effects of specific combining ability, which is an indication of the importance of the arrangement of inbred lines in double crosses to get a good performance. On the basis of the results shown in Tables $(5,6$ and 7$)$, the bilateral arrangement $S_{(56)(-}$ -) gave desired performance of specific combining ability of this type for all characters, followed by bilateral arrangements $S_{(25)(-)}, S_{(34)(-)}, S_{(23)(-)}$ and $\mathrm{S}_{(45)(-)}$. which performed well for $5,5,4$ and 4 characters including GYP, respectively.

According to the bilateral arrangement $\mathrm{S}_{(\mathrm{i})(\mathrm{j}-)}$, outweighed the arrangement $S_{(1-)(5-)}$ of inbred lines ZP301 and DK17 with good performance for all characters, followed by the arrangements $S_{(2-)(4-)}$, $S_{(3-)(6-)}, S_{\left(2_{-}\right)(6-)}$ and $S_{(3-)(5-)}$. which were performed well for $6,5,4$ and 4 characters, respectively.

Table (8), shows the 3-line interaction effects of lines $i, j$ and $k$ appearing together irrespective of the arrangement, and it seems that the consensus number of three inbred lines that gave the desirable specific effects were $9,13,6,4,14,11$ and 15 for characters NDS, PH, EH, NRE, NGR, $300 \mathrm{gw}$ and GYP, respectively. It is clear that the presence of the three lines IK58, ZP707 and DK17 together $\left(S_{235}\right)$ has given desirable effects of the specific combining ability of this type for all the studied characters, followed by the two interactions $S_{125}, S_{146}$ as both of them are desirable 


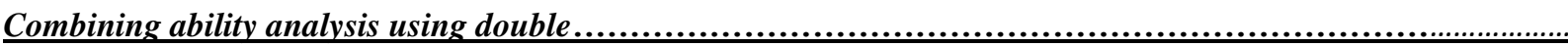

Table (4): General combining ability effects of the lines for grain yield and some studied traits.

\begin{tabular}{|c|c|c|c|c|c|c|c|}
\hline \multirow{2}{*}{ Lines } & \multicolumn{7}{|c|}{ Characters } \\
\hline & NDS & PH & EH & NRE & NGR & $300 \mathrm{~g}$ & GYP \\
\hline 1.ZP301 & -0.015 & -0.244 & 0.148 & 0.104 & -0.167 & -0.092 & $\begin{array}{l}-0.675 \\
\end{array}$ \\
\hline 2.IK58 & -0.159 & 1.556 & 1.681 & -0.096 & -0.300 & 0.921 & 0.591 \\
\hline 3.ZP707 & -0.070 & 0.878 & -0.229 & 0.170 & 0.778 & 0.208 & 3.745 \\
\hline $4.0 \mathrm{H} 40$ & 0.463 & 0.111 & -0.629 & -0.229 & -0.144 & -0.197 & -0.951 \\
\hline 5.DK17 & -0.504 & -0.544 & 0.381 & -0.163 & -0.122 & -0.786 & -3.027 \\
\hline 6.UN44052 & 0.285 & -1.756 & -1.352 & 0.215 & -0.044 & -0.052 & 0.317 \\
\hline
\end{tabular}

Table (5): The 2-line interaction effects of lines $\mathbf{i}$ and $\mathbf{j}$ appearing together irrespective of arrangement for grain yield and some studied traits.

\begin{tabular}{|c|c|c|c|c|c|c|c|}
\hline \multirow{2}{*}{$\mathbf{S}_{2 \mathrm{ij}}$} & \multicolumn{7}{|c|}{ Characters } \\
\hline & NDS & PH & EH & NRE & NGR & $300 \mathrm{~g}$ & GYP \\
\hline$S_{12}$ & -0.285 & $\mathbf{0 . 6 5 2}$ & 1.044 & $\mathbf{0 . 1 3 3}$ & -1.204 & -0.155 & -4.892 \\
\hline$S_{13}$ & -0.096 & -0.726 & 0.770 & 0.089 & -0.244 & -0.207 & -1.547 \\
\hline$S_{14}$ & -0.204 & -1.089 & 0.207 & 0.378 & -0.278 & -0.668 & -2.139 \\
\hline$S_{15}$ & $\begin{array}{l}0.004 \\
\end{array}$ & -2.470 & -1.044 & 0.200 & -0.215 & $\begin{array}{l}0.086 \\
\end{array}$ & 1.738 \\
\hline$S_{16}$ & 0.419 & 0.944 & 0.652 & 0.341 & $\mathbf{0 . 2 0 7}$ & -0.068 & -0.582 \\
\hline$S_{23}$ & 0.152 & 3.167 & 3.256 & 0.193 & 0.167 & $\begin{array}{l}\mathbf{0 . 4 3 8} \\
\end{array}$ & -0.163 \\
\hline $\mathbf{S}_{24}$ & 0.119 & -2.159 & -1.641 & -0.148 & 0.441 & 0.606 & 3.658 \\
\hline$S_{25}$ & -0.193 & 2.793 & 1.126 & 0.007 & 0.178 & $-\mathbf{- 0 . 3 4 3}$ & 0.256 \\
\hline$S_{26}$ & \begin{tabular}{|l|l|}
0.019 \\
\end{tabular} & -3.852 & -1.807 & -0.074 & -0.215 & \begin{tabular}{|l|l|}
0.199 \\
\end{tabular} & 0.383 \\
\hline $\mathbf{S}_{34}$ & 0.196 & $\mathbf{0 . 8 5 2}$ & -1.507 & -0.229 & -0.193 & -0.292 & -1.305 \\
\hline $\mathbf{S}_{35}$ & -0.281 & -2.974 & -1.093 & $\mathbf{0 . 0 3 7}$ & 0.285 & $\begin{array}{l}0.376 \\
\end{array}$ & 0.693 \\
\hline$S_{36}$ & $-\mathbf{- 0 . 0 7 0}$ & $\begin{array}{l}\mathbf{0 . 0 7 0} \\
\end{array}$ & -1.359 & 0.289 & $\begin{array}{l}0.429 \\
\end{array}$ & -0.293 & 4.718 \\
\hline $\mathbf{S}_{45}$ & $\mathbf{0 . 1 8 5}$ & 1.756 & 1.419 & -0.044 & -0.126 & -0.522 & -2.014 \\
\hline$S_{46}$ & $\mathbf{0 . 1 3 7}$ & 0.263 & 1.189 & 0.022 & -0.222 & 0.494 & -0.501 \\
\hline$S_{56}$ & \begin{tabular}{l|c|}
-0.248 \\
\end{tabular} & $\begin{array}{c}\mathbf{- 0 . 1 3 7} \\
\end{array}$ & 0.270 & -0.156 & -0.578 & -0.570 & $\begin{array}{l}-5.049 \\
\end{array}$ \\
\hline
\end{tabular}

Table (6): The 2-line interaction effects of lines $\mathbf{i}$ and $\mathbf{j}$ due to a particular arrangement (ij) (--) for grain yield and some studied traits.

\begin{tabular}{|c|c|c|c|c|c|c|c|}
\hline \multirow{2}{*}{$\mathbf{S}_{(\mathbf{i j})(. .)}$} & \multicolumn{7}{|c|}{ Characters } \\
\hline & NDS & $\mathbf{P H}$ & EH & NRE & NGR & $300 \mathrm{~g}$ & GYP \\
\hline $\mathbf{S}_{(12)(. .)}$ & -1.711 & 10.748 & 7.629 & -0.059 & 1.981 & 0.949 & 9.635 \\
\hline$S_{(13)(. .)}$ & -0.044 & 5.193 & 8.759 & -0.059 & -2.167 & -2.735 & -8.666 \\
\hline$S_{(14)(. .)}$ & -0.137 & 5.989 & 6.889 & 0.052 & -0.389 & -0.988 & 3.589 \\
\hline $\mathbf{S}_{(15)(. .)}$ & 1.678 & -9.307 & -7.370 & -0.948 & -0.574 & -1.118 & -13.851 \\
\hline$S_{(16)(. .)}$ & 0.363 & -10.178 & -17.389 & -0.022 & 2.815 & 4.820 & 16.042 \\
\hline$S_{(23)(. .)}$ & 1.296 & -12.111 & -5.648 & 0.593 & 1.111 & 4.672 & 12.659 \\
\hline $\mathbf{S}_{(24)(. .)}$ & 0.241 & -4.296 & -4.963 & 0.000 & -1.796 & -1.754 & -15.246 \\
\hline$S_{(25)(. .)}$ & 0.685 & 5.241 & 0.204 & 0.111 & 0.889 & -0.125 & 7.196 \\
\hline$S_{(26)(. .)}$ & -0.481 & 0.907 & 2.481 & -0.852 & -1.852 & -3.557 & -12.894 \\
\hline $\mathbf{S}_{(34)(. .)}$ & -0.481 & 5.648 & -4.241 & -0.741 & 2.370 & 2.437 & 8.794 \\
\hline $\mathbf{S}_{(35)(. .)}$ & -1.648 & -5.926 & -3.667 & 0.259 & -0.019 & -1.747 & 1.290 \\
\hline$S_{(36)(. .)}$ & 0.907 & 7.685 & 4.500 & -0.259 & -0.963 & -2.442 & -12.728 \\
\hline $\mathbf{S}_{(45)(. .)}$ & 0.241 & 0.778 & 1.222 & -0.037 & -0.074 & 1.151 & -0.001 \\
\hline$S_{(46)(. .)}$ & 0.167 & -7.629 & 0.796 & 0.519 & 0.222 & -0.661 & 4.214 \\
\hline$S_{(56)(. .)}$ & -0.926 & 9.704 & 9.315 & 0.407 & 0.111 & 2.025 & 6.716 \\
\hline
\end{tabular}


Table (7): The 2-line interaction effects of lines $i$ and $\mathbf{j}$ due to a particular arrangement (i-) (j-) for grain yield and some studied traits.

\begin{tabular}{|c|c|c|c|c|c|c|c|}
\hline \multirow{2}{*}{$\begin{array}{l}\text { Single } \\
\text { cross } \\
S_{(\mathrm{i})(\mathrm{i}-)}\end{array}$} & \multicolumn{7}{|c|}{ Characters } \\
\hline & NDS & PH & EH & NRE & NGR & $300 \mathrm{~g}$ & GYP \\
\hline $\mathbf{S}_{(1-)(2-)}$ & 0.900 & -4.641 & -4.259 & -0.281 & -0.941 & -0.196 & -2.793 \\
\hline$S_{(1-)(3-)}$ & 0.067 & -1.863 & -4.824 & -0.281 & 1.583 & 1.646 & 6.357 \\
\hline$S_{(1-)(4-)}$ & 0.113 & -2.261 & -3.889 & -0.337 & 0.694 & 0.773 & 0.229 \\
\hline$S_{(1-)(5-)}$ & -0.794 & 5.387 & 3.241 & 0.163 & 0.787 & 0.838 & 8.949 \\
\hline$S_{(1-)(6-)}$ & -0.137 & 5.822 & 8.250 & -0.300 & -0.907 & -2.131 & -5.996 \\
\hline$S_{(2-)(3-)}$ & -0.648 & 6.056 & 2.824 & -0.296 & -0.556 & -2.336 & -6.329 \\
\hline $\mathbf{S}_{(2-)(4-)}$ & -0.120 & 2.148 & 2.481 & 0.000 & 0.898 & 0.877 & 7.623 \\
\hline $\mathbf{S}_{(2-)(5-)}$ & -0.343 & -2.620 & -0.102 & -0.056 & -0.444 & 0.063 & -3.598 \\
\hline$S_{(2-)(6-)}$ & 0.241 & -0.454 & -1.241 & 0.426 & 0.926 & 1.779 & 6.447 \\
\hline $\mathbf{S}_{(3-)(4-)}$ & 0.241 & -2.824 & 2.120 & 0.370 & -1.185 & -1.218 & -4.397 \\
\hline $\mathbf{S}_{(3-)(5-)}$ & 0.824 & 2.963 & 1.833 & -0.129 & 0.009 & 0.873 & -0.645 \\
\hline $\mathbf{S}_{(3-)(6-)}$ & -0.454 & -3.843 & -2.250 & 0.129 & 0.481 & 1.221 & 6.364 \\
\hline $\mathbf{S}_{(4-)(5-)}$ & -0.120 & -0.389 & -0.611 & 0.019 & 0.037 & -0.575 & 0.001 \\
\hline$S_{(4-)(6-)}$ & -0.083 & 3.815 & -0.398 & -0.259 & -0.111 & 0.330 & -2.107 \\
\hline$S_{(5-)(6-)}$ & 0.463 & -4.852 & -4.657 & -0.204 & -0.056 & -1.013 & -3.358 \\
\hline
\end{tabular}

Table (8): The 3-line interaction effects of lines $i, j$ and $k$ appearing together irrespective of arrangement for grain yield and some studied traits.

\begin{tabular}{|c|c|c|c|c|c|c|c|}
\hline \multirow{2}{*}{$\begin{array}{c}3 \text { way cross } \\
S_{3 \mathrm{ijk}}\end{array}$} & \multicolumn{7}{|c|}{ characters } \\
\hline & NDS & $\mathbf{P H}$ & EH & NRE & NGR & $300 \mathrm{~g}$ & GYP \\
\hline$S_{123}$ & -0.029 & 4.319 & 3.352 & -0.474 & -0.052 & 0.464 & -2.425 \\
\hline$S_{124}$ & -0.348 & -1.115 & -1.974 & -0.393 & 0.396 & 0.305 & 2.370 \\
\hline$S_{125}$ & -0.129 & 2.674 & -0.796 & -0.437 & 0.289 & 0.307 & $\mathbf{3 . 5 3 7}$ \\
\hline$S_{126}$ & $\mathbf{0 . 2 3 3}$ & 0.315 & -1.456 & -0.504 & 0.293 & 0.451 & 0.229 \\
\hline$S_{134}$ & -0.111 & 0.744 & -1.478 & -0.607 & 0.363 & -0.397 & -0.299 \\
\hline $\mathbf{S}_{135}$ & -0.059 & -4.244 & -2.652 & -0.541 & 0.996 & 1.222 & 6.268 \\
\hline$S_{136}$ & 0.304 & 2.619 & -0.644 & -0.274 & 1.537 & 0.155 & 6.858 \\
\hline$S_{145}$ & 0.122 & 0.378 & -0.570 & -0.200 & 0.759 & -0.002 & 4.534 \\
\hline$S_{146}$ & 0.226 & 2.704 & 1.474 & -0.119 & 1.059 & 0.615 & 2.612 \\
\hline$S_{156}$ & 0.370 & 1.141 & -1.033 & -0.496 & 0.859 & 0.502 & 2.632 \\
\hline $\mathbf{S}_{234}$ & 0.389 & 1.011 & -0.167 & -0.133 & 0.304 & 0.441 & 1.061 \\
\hline $\mathbf{S}_{235}$ & -0.078 & 2.356 & 2.678 & 0.267 & 0.511 & 0.357 & 0.349 \\
\hline $\mathbf{S}_{236}$ & 0.081 & -0.374 & 0.056 & 0.311 & $\mathbf{0 . 2 3 7}$ & -0.014 & 3.386 \\
\hline $\mathbf{S}_{245}$ & 0.178 & 2.015 & 0.426 & -0.022 & 0.681 & -0.238 & 3.029 \\
\hline$S_{246}$ & 0.078 & -5.252 & -2.159 & -0.163 & 0.167 & 1.075 & 3.555 \\
\hline $\mathbf{S}_{256}$ & -0.296 & -0.481 & -0.648 & $-\mathbf{- 0 . 2 0 7}$ & -0.459 & -0.741 & -3.705 \\
\hline$S_{345}$ & $\mathbf{0 . 1 3 7}$ & -0.515 & -1.022 & -0.163 & -0.204 & -0.179 & -2.548 \\
\hline$S_{346}$ & $\mathbf{0 . 0 3 7}$ & 1.441 & -0.941 & 0.029 & -0.181 & -0.078 & 1.875 \\
\hline$S_{356}$ & -0.504 & -2.567 & -1.781 & 0.096 & -0.067 & -0.277 & 0.016 \\
\hline$S_{456}$ & -0.007 & 2.611 & 3.411 & -0.119 & -0.822 & -0.253 & -6.344 \\
\hline
\end{tabular}

specific effects for five characters, including the GYP, while the desired specific effects were present in four characters for each of the interactions $\mathrm{S}_{124}, \mathrm{~S}_{126}, \mathrm{~S}_{135}, \mathrm{~S}_{136}, \mathrm{~S}_{156}, \mathrm{~S}_{234}$ and $\mathrm{S}_{245}$.

Table (9) shows the same interaction effects between lines $\mathrm{i}, \mathrm{j}$ and $\mathrm{k}$ but due to particular arrangement (ij) (k). Comparison with the results of Table (8) shows clear differences in the behavior of interactions towards all studied characters, which is an indication of the importance the line arrangement in double cross hybrids to get good hybrid characterizes by its field specifications and productivity. It seems that the interaction arrangements, $S_{(12)(6-)}, S_{(15)(2-)}$, $\mathrm{S}_{(36)(5-)}, \mathrm{S}_{(23)(1-)}, \mathrm{S}_{(24)(1-)}, \mathrm{S}_{(56)(1-)}$, and $\mathrm{S}_{(46)(2-)}$ all of hem came with desirable specific combining ability effects for six characters, including GYP. 


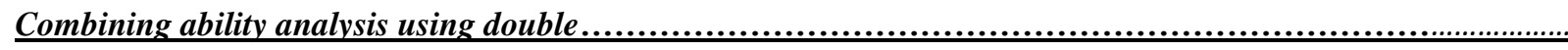

Table (9): The 3-line interaction effects of lines $\mathbf{i}, \mathrm{j}$ and $\mathrm{k}$ due to a particular arrangement (ij)(k) for grain yield and some studied traits.

\begin{tabular}{|c|c|c|c|c|c|c|c|}
\hline \multirow{2}{*}{$\begin{array}{l}3 \text { way cross } \\
S_{(i \mathrm{ij})(\mathrm{k}-)}\end{array}$} & \multicolumn{7}{|c|}{ Characters } \\
\hline & NDS & PH & EH & NRE & NGR & $300 \mathrm{~g}$ & GYP \\
\hline$S_{(12)(3-)}$ & 0.515 & $\begin{array}{l}-1.941 \\
\end{array}$ & $\begin{array}{l}-0.481 \\
\end{array}$ & 0.489 & -2.120 & -4.311 & -14.116 \\
\hline$S_{(12)(4-)}$ & 1.089 & -3.524 & -1.167 & 0.174 & -2.463 & 1.373 & -10.103 \\
\hline$S_{(12)(5-)}$ & 0.070 & -9.107 & -2.028 & 0.396 & -0.694 & -2.652 & -3.567 \\
\hline$S_{(12)(6-)}$ & -0.170 & 0.402 & -1.379 & 0.452 & 0.963 & 3.340 & 8.704 \\
\hline$S_{(13)(2-)}$ & -0.096 & -2.719 & 1.269 & 0.711 & -0.120 & 3.780 & -4.100 \\
\hline $\mathbf{S}_{(13)(4-)}$ & -0.754 & -0.811 & -2.213 & -0.789 & -0.157 & -2.683 & -6.860 \\
\hline$S_{(13)(5-)}$ & 0.867 & -3.061 & -4.944 & 0.544 & -0.852 & 0.353 & 5.419 \\
\hline $\mathbf{S}_{(13)(6-)}$ & -0.179 & -2.024 & -0.796 & 1.044 & 0.963 & -0.016 & 4.759 \\
\hline$S_{(14)(2-)}$ & -0.050 & -8.829 & -4.444 & 0.007 & -1.796 & -1.932 & -6.569 \\
\hline$S_{(14)(3-)}$ & 0.163 & 0.550 & 0.704 & 1.267 & -0.157 & 0.254 & 8.082 \\
\hline$S_{(14)(5-)}$ & -1.393 & 0.050 & 2.185 & 0.137 & 1.824 & 1.974 & -5.097 \\
\hline$S_{(14)(6-)}$ & 1.209 & -1.181 & -3.259 & -0.011 & -1.815 & -0.608 & -9.451 \\
\hline$S_{(15)(2-)}$ & 0.098 & 6.865 & 2.139 & 1.063 & 2.250 & 2.442 & 17.878 \\
\hline$S_{(15)(3-)}$ & -0.717 & -1.311 & 0.361 & -0.344 & -1.352 & -0.249 & -8.719 \\
\hline$S_{(15)(4-)}$ & $\begin{array}{l}-0.337 \\
\end{array}$ & 6.772 & 7.685 & 1.414 & -1.120 & -0.489 & 2.708 \\
\hline$S_{(15)(6-)}$ & -0.929 & -6.441 & -0.741 & 0.267 & -1.537 & -1.885 & -7.463 \\
\hline$S_{(16)(2-)}$ & -1.059 & 5.902 & 7.370 & -0.048 & -2.176 & -5.394 & -13.863 \\
\hline$S_{(16)(3-)}$ & -0.235 & 1.143 & 6.315 & 0.322 & -0.287 & 1.359 & -1.051 \\
\hline$S_{(16)(4-)}$ & -0.319 & -3.598 & 2.157 & 0.989 & 0.713 & -0.273 & 4.578 \\
\hline$S_{(16)(5-)}$ & 1.043 & 3.309 & 3.620 & 0.211 & -3.398 & -1.813 & -15.152 \\
\hline$S_{(23)(1-)}$ & -0.596 & 1.726 & 0.991 & 0.044 & 0.241 & -0.584 & 10.119 \\
\hline $\mathbf{S}_{(23)(4-)}$ & -0.565 & 7.417 & 6.898 & 0.370 & -1.454 & -1.028 & -5.296 \\
\hline$S_{(23)(5-)}$ & 0.407 & -1.306 & -1.713 & $\begin{array}{l}0.037 \\
\end{array}$ & 0.361 & 0.232 & -2.252 \\
\hline $\mathbf{S}_{(23)(6-)}$ & -0.602 & 3.296 & 0.065 & -0.629 & -0.926 & -3.663 & -17.929 \\
\hline$S_{(24)(1-)}$ & -1.217 & 9.420 & 7.889 & 1.063 & 2.259 & -0.555 & 8.575 \\
\hline$S_{(24)(3-)}$ & -0.870 & 0.139 & -2.129 & -0.741 & 0.907 & 3.156 & 4.231 \\
\hline$S_{(24)(5-)}$ & 1.407 & 3.935 & 1.083 & 0.259 & -0.648 & 1.249 & 6.126 \\
\hline$S_{(24)(6-)}$ & 0.379 & -10.176 & -1.287 & -0.167 & -1.389 & -2.468 & -6.386 \\
\hline$S_{(25)(1-)}$ & -0.346 & -0.691 & 1.667 & -0.215 & -3.556 & -0.905 & -22.408 \\
\hline$S_{(25)(3-)}$ & -0.009 & -3.000 & -1.269 & 0.759 & 1.250 & 1.261 & 6.665 \\
\hline$S_{(25)(4-)}$ & -0.481 & -8.481 & -4.444 & -0.574 & 0.991 & -1.244 & -0.616 \\
\hline $\mathbf{S}_{(25)(6-)}$ & 0.093 & 5.954 & 4.435 & 0.333 & -0.241 & 0.641 & 6.465 \\
\hline$S_{(26)(1-)}$ & 1.052 & -9.237 & -4.213 & 0.841 & -0.787 & 0.939 & -2.939 \\
\hline$S_{(26)(3-)}$ & 0.954 & -2.231 & 1.648 & 0.204 & -0.148 & 1.858 & 6.851 \\
\hline$S_{(26)(4-)}$ & 0.019 & 1.463 & -2.676 & 0.444 & 1.361 & -0.349 & 5.692 \\
\hline$S_{(26)(5-)}$ & -1.602 & 8.120 & 3.352 & -0.222 & 0.759 & 0.736 & 0.591 \\
\hline$S_{(34)(1-)}$ & -0.309 & 5.800 & -3.074 & -0.344 & 1.870 & 4.969 & 3.872 \\
\hline $\mathbf{S}_{(34)(2-)}$ & 0.713 & 0.917 & -11.129 & -0.741 & 4.102 & 1.528 & 14.256 \\
\hline$S_{(34)(5-)}$ & -1.796 & $\mathbf{1 0 . 1 7 6}$ & -3.824 & -1.444 & 1.509 & 0.372 & 1.106 \\
\hline $\mathbf{S}_{(34)(6-)}$ & -1.074 & 10.370 & -2.583 & -0.759 & 3.704 & 4.943 & 22.038 \\
\hline$S_{(35)(1-)}$ & -0.328 & 1.439 & 6.361 & 1.044 & 0.204 & -1.218 & -4.798 \\
\hline$S_{(35)(2-)}$ & $\begin{array}{l}-0.398 \\
\end{array}$ & 4.306 & 2.981 & -0.796 & -1.611 & -1.493 & -4.413 \\
\hline $\mathbf{S}_{(35)(4-)}$ & 0.787 & -0.491 & -4.879 & 0.389 & 2.093 & 3.288 & 9.961 \\
\hline$S_{(35)(6-)}$ & 1.528 & $\begin{array}{c}-0.306 \\
\end{array}$ & -0.204 & -0.481 & -1.333 & 0.799 & -4.740 \\
\hline$S_{(36)(1-)}$ & 0.237 & -2.052 & -3.741 & -0.122 & -2.676 & -2.459 & -11.806 \\
\hline$S_{(36)(2-)}$ & -0.352 & -1.065 & -1.713 & 0.426 & 1.074 & 1.805 & 11.079 \\
\hline$S_{(36)(4-)}$ & 0.231 & -4.269 & -1.333 & 0.074 & 0.037 & 1.270 & 3.892 \\
\hline$S_{(36)(5-)}$ & -1.083 & -1.278 & 2.879 & 0.296 & 1.861 & 1.453 & 6.864 \\
\hline$S_{(45)(1-)}$ & 1.552 & -9.756 & $\begin{array}{r}-8.093 \\
\end{array}$ & $\begin{array}{l}-0.307 \\
\end{array}$ & -2.704 & -2.599 & -5.709 \\
\hline$S_{(45)(2-)}$ & -0.926 & 4.546 & 3.361 & 0.315 & -0.343 & -0.005 & -5.512 \\
\hline$S_{(45)(3-)}$ & 0.287 & -1.213 & 2.343 & -0.056 & -0.046 & -0.005 & 2.124 \\
\hline$S_{(45)(6-)}$ & $\begin{array}{l}-0.667 \\
\end{array}$ & -4.000 & -2.500 & 0.556 & 2.556 & -0.256 & 5.146 \\
\hline$S_{(46)(1-)}$ & -1.069 & 1.846 & 2.879 & 0.267 & -0.898 & -0.233 & -3.224 \\
\hline$S_{(46)(2-)}$ & -0.398 & 8.713 & 3.963 & -0.278 & 0.028 & 2.817 & 0.694 \\
\hline$S_{(46)(3-)}$ & 0.120 & 2.370 & -2.444 & -0.426 & -0.185 & -2.558 & -12.739 \\
\hline$S_{(46)(5-)}$ & 1.667 & -14.944 & -8.861 & 0.389 & 0.222 & -1.079 & 7.105 \\
\hline$S_{(56)(1-)}$ & -0.291 & 0.198 & -1.102 & 0.767 & 2.935 & 2.583 & 14.518 \\
\hline$S_{(56)(2-)}$ & 1.509 & -14.074 & -7.787 & -0.111 & -0.519 & -1.378 & -7.056 \\
\hline $\mathbf{S}_{(56)(3-)}$ & -0.444 & 1.583 & -2.676 & 0.185 & -0.528 & -2.252 & -2.123 \\
\hline$S_{(56)(4-)}$ & 0.093 & 1.611 & 2.843 & -0.833 & -2.667 & -1.350 & -14.754 \\
\hline
\end{tabular}


The 4-line interaction effects of lines i, j, $\mathrm{k}$ and $\mathrm{l}$ appearing together irrespective of arrangement for all characters are presented in Table (10). It is shown than 10, 9, 10, 12 of the 4-line interactions gave desired specific combining ability for NDS, PH, EH AND NRE, While desirable specific effects were shown in four Quad interactions for each of NGR, $300 \mathrm{gw}$ and GYP. It is clear from Table (10) that the specific combining ability was desired for all characters in the interaction $S_{1356}$, for NDS in the interaction $\mathrm{S}_{2345}$, for NDS, $\mathrm{PH}, \mathrm{EH}$, NRE and $300 \mathrm{~g}$ in the interaction $S_{1235}$ and for a lower number of characters in the rest of interactions. When developing the four pure lines in the order $S_{(\mathrm{ij})(\mathrm{kl})}($ Table 11), all four combination could be of three cases. For example, the superior ranking in Table (10) $\left(S_{1356}\right)$ becomes according to the order in Table (11) in three forms: $S_{(13)(56)}$, $S_{(15)(36)}$ and $S_{(16)(35)}$, and these three arrangements, which include the four inbred lines, giving desirable specific combining ability effects for 6 , 2 and three characters respectively, as well as the case for the other Quartet consensus between inbred lines of maize. These results confirm the importance of the order of inbred lines of maize in double cross hybrids to get superior hybrids characterized by good productivity and at the same time by high specific combining ability in the desired direction. On the basis of the results in Table (10), it is clear that the both double cross hybrids (ZP301x ZP707) $x$ (IK58xOH40) and (ZP301xUN44052) $x$ (OH40xDK17) have shown desired effects of specific combining ability for all studied characters, followed by double crosses $(1 \times 2) \times(3 \times 6), \quad(1 \times 2) \times(4 \times 5), \quad(1 \times 3) \times(5 \times 6)$, $(1 \times 4) \times(3 \times 6), \quad(1 \times 5) \times(2 \times 3), \quad(1 \times 5) \times(2 \times 6)$, $(1 \times 5) \times(4 \times 6), \quad(2 \times 4) \times(5 \times 6), \quad(2 \times 5) \times(3 \times 6)$, $(2 \times 6) \times(4 \times 5)$ and $(3 \times 5) \times(4 \times 6)$, as each of them gave desirable specific effects for six characters, including GYP, and it is concluded the possibility of the use of these hybrids in future breeding programs.

It is concluded from the above results that nonadditive genetic effects (dominance and epistasis of) were more important in the inheritance of all studied characters.

Therefore, the appropriate breeding method that can be adopted to improve these characters either the production of hybrid varieties or by recurrent selection for specific combining ability. The results recommended the two lines ZP707 and IK58 that showed significant desirable general

Table (10): The 4-line interaction effects of lines $i, j, k$ and $l$ appearing together irrespective of arrangement for grain yield and some studied traits.

\begin{tabular}{|c|c|c|c|c|c|c|c|}
\hline \multirow{2}{*}{$S_{4(j \mathrm{jkl})}$} & \multicolumn{7}{|c|}{ characters } \\
\hline & NDS & PH & EH & NRE & NGR & $300 \mathrm{~g}$ & GYP \\
\hline $\mathbf{S}_{1234}$ & -0.615 & 0.422 & 2.670 & 0.104 & -2.567 & -1.429 & -16.488 \\
\hline$S_{1235}$ & -0.426 & 0.967 & 6.437 & 0.704 & -1.478 & 1.172 & -4.917 \\
\hline$S_{1236}$ & 0.507 & 4.233 & 5.393 & 0.881 & -1.111 & -1.139 & -6.112 \\
\hline$S_{1245}$ & -0.515 & -0.378 & -1.607 & 1.104 & -0.444 & -1.592 & 6.042 \\
\hline$S_{1246}$ & -0.359 & -10.722 & -2.541 & 0.726 & -0.800 & 1.149 & -2.687 \\
\hline$S_{1256}$ & 0.107 & 0.100 & -2.774 & $\begin{array}{c}-0.007 \\
\end{array}$ & -2.211 & -1.444 & -10.758 \\
\hline $\mathbf{S}_{1345}$ & -0.159 & -11.422 & -4.863 & 0.281 & -1.300 & -0.828 & -3.808 \\
\hline$S_{1346}$ & -0.004 & 5.900 & 2.204 & 0.904 & -0.044 & -1.719 & -0.844 \\
\hline$S_{1356}$ & -0.037 & -9.611 & -5.085 & 0.504 & 0.767 & 0.536 & 7.286 \\
\hline$S_{1456}$ & 0.596 & 5.600 & 9.204 & 1.126 & -0.978 & -0.372 & -8.875 \\
\hline $\mathbf{S}_{2345}$ & 1.074 & 6.300 & 2.270 & 0.081 & 1.833 & 0.499 & 2.659 \\
\hline$S_{2346}$ & 0.619 & -5.156 & -4.552 & $\mathbf{0 . 0 3 7}$ & 0.644 & 1.696 & 12.964 \\
\hline $\mathbf{S}_{2356}$ & -0.970 & -1.667 & 0.215 & 0.607 & 0.178 & -1.157 & -0.742 \\
\hline$S_{2456}$ & -0.115 & -1.344 & 1.504 & -0.629 & -0.344 & -0.178 & -3.662 \\
\hline$S_{3456}$ & -0.593 & 2.111 & 0.415 & -0.229 & -2.144 & -0.767 & -10.544 \\
\hline
\end{tabular}




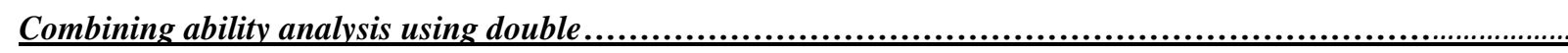

Table (11): The 4-line interaction effects of lines $\mathbf{i}, \mathbf{j}, \mathbf{k}$ and $\mathbf{l}$ due to a particular arrangement (ij)(kl) for grain yield and some studied traits.

\begin{tabular}{|c|c|c|c|c|c|c|c|}
\hline \multirow{2}{*}{$\begin{array}{l}\text { Double } \\
\text { cross } \\
S_{(\mathrm{ij})(\mathrm{kl})}\end{array}$} & \multicolumn{7}{|c|}{ Characters } \\
\hline & NDS & PH & $\mathrm{EH}$ & NRE & NGR & $300 \mathrm{~g}$ & GYP \\
\hline$S_{(12)(34)}$ & 0.441 & -25.061 & 7.259 & 0.137 & -8.139 & -8.638 & -28.292 \\
\hline$S_{(12)(35)}$ & -0.226 & 7.744 & -0.602 & -0.196 & 2.222 & 0.593 & 2.662 \\
\hline$S_{(12)(36)}$ & 1.496 & 4.772 & 3.398 & 0.415 & 1.806 & 2.406 & 11.393 \\
\hline$S_{(12)(45)}$ & 1.496 & 4.772 & 3.398 & 0.415 & 1.806 & 2.406 & 11.393 \\
\hline$S_{(12)(46)}$ & -0.226 & 7.744 & -0.602 & -0.196 & 2.222 & 0.593 & 2.662 \\
\hline$S_{(12)(56)}$ & -1.004 & -8.117 & -5.463 & -2.085 & -1.028 & -1.327 & -1.909 \\
\hline$S_{(13)(24)}$ & -1.898 & 2.978 & 0.143 & 0.315 & 3.756 & 12.093 & 24.092 \\
\hline$S_{(13)(25)}$ & 0.852 & 1.728 & 2.670 & -0.685 & 1.061 & 6.572 & 4.721 \\
\hline $\mathrm{S}_{(13)(26)}$ & -0.787 & -0.606 & 5.504 & -1.629 & 0.950 & 9.420 & 3.920 \\
\hline$S_{(13)(45)}$ & -0.087 & -0.506 & 1.843 & -1.585 & 0.028 & 0.616 & -2.942 \\
\hline$S_{(13)(46)}$ & 1.552 & 1.828 & -0.991 & -0.641 & 0.139 & -2.233 & -2.141 \\
\hline$S_{(13)(56)}$ & -1.198 & 3.078 & -3.519 & 0.359 & 2.833 & 3.289 & 17.229 \\
\hline$S_{(14)(23)}$ & 1.241 & 4.811 & 5.448 & -0.574 & 0.783 & -2.881 & -2.794 \\
\hline$S_{(14)(25)}$ & -3.037 & 0.700 & -4.552 & -1.185 & 1.172 & -1.768 & 11.001 \\
\hline$S_{(14)(26)}$ & -1.620 & -14.994 & -6.163 & -1.407 & -0.189 & -1.455 & 5.078 \\
\hline$S_{(14)(35)}$ & 0.524 & -9.006 & -2.379 & 1.081 & 0.222 & 4.047 & 19.640 \\
\hline$S_{(14)(36)}$ & -0.893 & 6.689 & -0.769 & 1.304 & 1.583 & 3.761 & 25.563 \\
\hline$S_{(14)(56)}$ & 2.469 & 9.439 & 6.315 & -0.141 & 1.194 & -0.289 & -3.174 \\
\hline$S_{(15)(23)}$ & -1.120 & 11.478 & 5.004 & -0.629 & 2.506 & 9.118 & 29.917 \\
\hline$S_{(15)(24)}$ & 0.519 & 10.950 & 3.698 & -1.129 & 1.478 & 4.249 & 8.424 \\
\hline$S_{(15)(26)}$ & 0.685 & 31.922 & 6.865 & 1.093 & 4.617 & 5.726 & 28.682 \\
\hline$S_{(15)(34)}$ & 0.607 & 0.078 & 18.815 & 2.026 & -4.861 & -7.994 & -30.132 \\
\hline$S_{(15)(36)}$ & -1.004 & -3.950 & 2.926 & -2.419 & -0.889 & -2.160 & -24.008 \\
\hline$S_{(15)(46)}$ & -0.550 & 10.217 & 8.685 & 0.193 & -2.361 & 2.192 & 20.682 \\
\hline$S_{(16)(23)}$ & -2.120 & 6.311 & 2.754 & -1.463 & -3.050 & -9.371 & -22.025 \\
\hline$S_{(16)(24)}$ & -0.093 & 13.200 & 13.893 & -1.463 & -3.661 & -8.080 & -20.935 \\
\hline$S_{(16)(25)}$ & -0.454 & 3.422 & 12.670 & -1.241 & -2.939 & -4.041 & -22.055 \\
\hline$S_{(16)(34)}$ & 1.913 & -16.533 & 21.843 & 1.026 & -7.083 & -2.858 & -28.527 \\
\hline$S_{(16)(35)}$ & 0.829 & 10.189 & 10.343 & -1.419 & -0.694 & 1.317 & -1.025 \\
\hline$S_{(16)(45)}$ & -3.217 & 6.383 & 1.769 & 0.248 & 3.639 & 0.328 & 18.975 \\
\hline$S_{(23)(45)}$ & -1.231 & -1.333 & -7.019 & -0.074 & 0.167 & -1.907 & -0.354 \\
\hline$S_{(23)(46)}$ & -1.148 & -6.639 & -0.185 & -0.407 & -0.361 & 2.754 & 7.576 \\
\hline$S_{(23)(56)}$ & 2.379 & 7.972 & 7.204 & 0.481 & 0.194 & -0.847 & -7.223 \\
\hline$S_{(24)(35)}$ & 0.491 & -1.722 & -4.907 & -1.185 & 1.917 & 3.569 & 10.263 \\
\hline$S_{(24)(36)}$ & 0.185 & -14.444 & -10.519 & -2.019 & 0.972 & 2.069 & -4.391 \\
\hline$S_{(24)(56)}$ & -1.287 & 1.611 & -2.629 & 0.981 & 1.833 & 2.731 & 13.181 \\
\hline$S_{(25)(34)}$ & 1.463 & -22.861 & 16.065 & 3.093 & -5.944 & -3.758 & -17.849 \\
\hline$S_{(25)(36)}$ & -2.315 & 2.167 & -2.352 & 0.593 & 1.472 & 1.297 & 15.489 \\
\hline$S_{(25)(46)}$ & -0.972 & -3.389 & -1.370 & -0.907 & 0.722 & -3.941 & -11.681 \\
\hline$S_{(26)(34)}$ & 3.657 & -8.667 & 15.981 & 4.370 & -4.583 & -2.427 & 4.739 \\
\hline$S_{(26)(35)}$ & 1.074 & -17.361 & -2.824 & 0.481 & 0.000 & 6.101 & 25.429 \\
\hline$S_{(26)(45)}$ & -1.083 & 18.333 & 5.602 & -0.407 & 1.722 & 3.521 & 6.338 \\
\hline$S_{(34)(56)}$ & 0.352 & -26.528 & 8.148 & 0.759 & -9.139 & -9.195 & -32.340 \\
\hline$S_{(35)(46)}$ & 1.722 & 4.278 & 3.491 & 2.204 & 1.750 & 4.294 & 8.721 \\
\hline$S_{(36)(45)}$ & 2.167 & -2.667 & 9.796 & 1.815 & -2.917 & -0.482 & -9.550 \\
\hline
\end{tabular}


combining ability effects for more number of characters, and the double cross hybrids $(\mathrm{ZP} 301 \times \mathrm{ZP} 707) \quad \mathrm{x}$ (IK58xOH40) and (ZP301xUN44052) $x$ (OH40xDK17), that performed well for all characters are for future breeding programs.

\section{REFERENCES}

Allard R. W. (1970). Principles of Plant Breeding. New York, USA. John Wiley \& Sons.

Cruz J. C. and Pereira Filho I. A. (2008). Cultivares de Milho Disponíveis no Mercado de Sementes do Brasil para a Safra 2008/2009.

[http://www.cnpms.embrapa.br/publicacoes /milho/cultivares.htm]. Accessed November $1,2009$.

El-Hashash E. F. (2013). Heterosis and gene action among single and double-cross hybrids performances in Cotton. AmericanEurasian J. Agric. and Environ. Sci., 13 (4): 505-516.

Gomez K. A. and Gomez. A. A. (1983). Statistical Procedures For Agricultural Research. $2^{\text {nd }}$ ed., John Wiley and Sons, New York. USA.

Griffing B. (1956). Concept of general and specific combining ability in relation to diallel crossing systems. Aust. J. Biol. Sci. 9: 463-493.

Hallauer R. and Miranda. B. (1982). Quantitative
Genetics in Maize Breeding. Ames: Iowa State University Press. USA.

Jenkins M. T. (1934). Methods of estimating the performance of double crosses in corn.J Amer. Soc. Agron. 26: 199-204.

Jones D. F. (1918). The effects of inbreeding and cross breeding upon development. Connecticut. Agric. Exp. Stat. Bull. 207: 1100.

Jones D. F. (1922). The productiveness of single and double first generation corn hybrids. Agron., J. 14: 241-252.

Jugenheimer R. W. (1976). Corn Improvement, Seed Production and Uses. WileyInter Science Publication, John Wiley \& Sons. New York USA.

Rawlings J. O. and Cockerham. C. C. (1962). Analysis of double cross hybrid population. Biometrics, 18: 229-244.

Singh R. K. and Chaudhary. B. D. (2007). Biometrical Methods in Quantitative Genetics. Kalyani publisher, New DelhiLudhiana, ISBN 81-7663: 307-318.

Stoskopf N. S. Tomes and Christie B. R. (1993). Plant Breeding. Theory and Practice. San Francisco: Westview Press Inc., USA.

Troyer A. F. (2009). Development of Hybrid Corn and the Seed Corn Industry. In: Handbook of Maize: Genetics and Genomics (Bennetzen JL and Hake S, eds.). Springer verlag, New York, 87-114, USA.

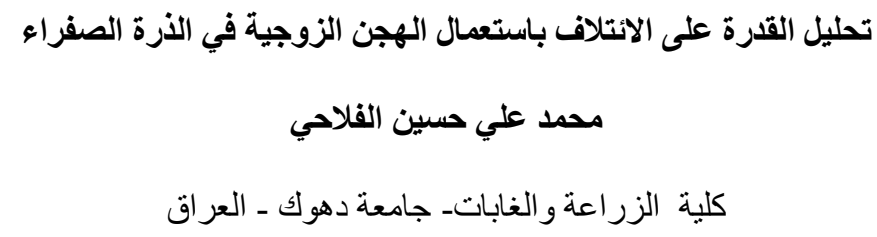

استخدمت في هذه الدراسة سلالات التربية الداخلية للذرة الصفراء و هي

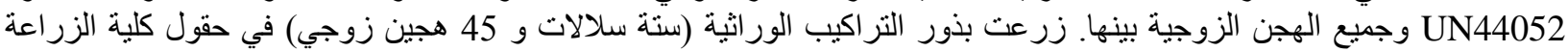

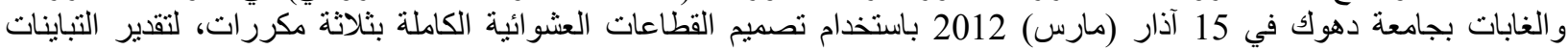

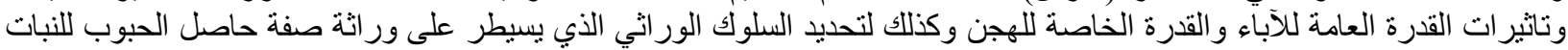

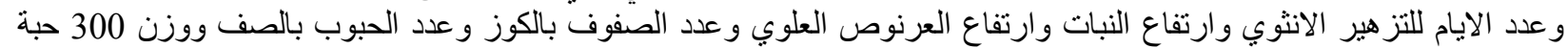

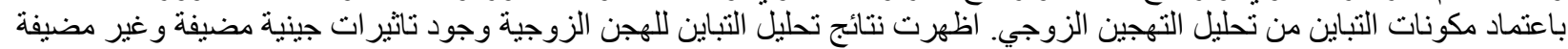

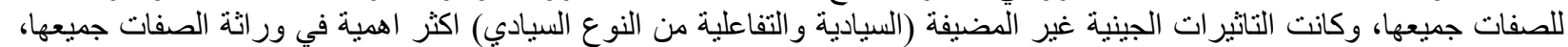

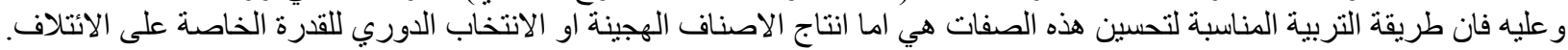

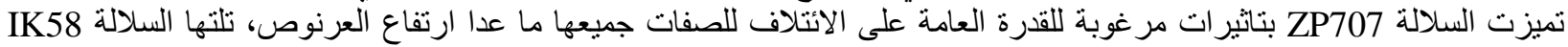

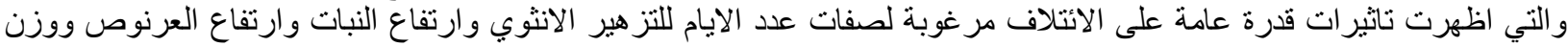

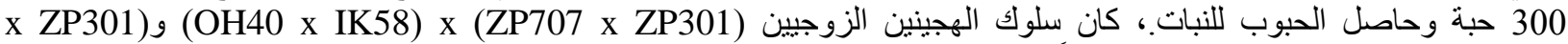
(DK17 x OH40) x (UN44052 مميز اً للصفات جميعها، ويمكن استخدامهما في بر امج التربية المستقبلية.

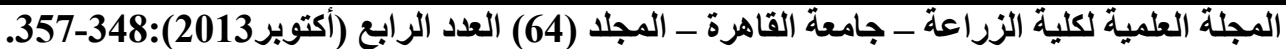

